OPEN ACCESS

Edited by:

Johann G. Zaller,

University of Natural Resources and

Life Sciences Vienna, Austria

Reviewed by:

Scott Nicholas Johnson,

Western Sydney University, Australia

Leif Richardson,

University of Vermont, United States

*Correspondence:

G. F. Veen

c.veen@nioo.knaw.nl

tThese authors have contributed equally to this work

¥Present address: Edmundo Barrios,

Food and Agriculture Organization of the United Nations, Rome, Italy

Specialty section:

This article was submitted to

Agroecology,

a section of the journal

Frontiers in Ecology and Evolution

Received: 16 January 2019

Accepted: 25 July 2019

Published: 14 August 2019

Citation:

Veen GF, Wubs ERJ, Bardgett RD, Barrios E, Bradford MA, Carvalho S, De Deyn GB, de Vries FT, Giller KE, Kleijn D, Landis DA, Rossing WAH,

Schrama M, Six J, Struik PC, van Gils S, Wiskerke JSC, van der Putten WH and Vet LEM (2019) Applying the

Aboveground-Belowground

Interaction Concept in Agriculture:

Spatio-Temporal Scales Matter.

Front. Ecol. Evol. 7:300.

doi: 10.3389/fevo.2019.00300

\section{Applying the Aboveground-Belowground Interaction Concept in Agriculture: Spatio-Temporal Scales Matter}

\author{
G. F. Veen ${ }^{1 \star t}$, E. R. Jasper Wubs ${ }^{1,2 \dagger}$, Richard D. Bardgett ${ }^{3}$, Edmundo Barrios ${ }^{4 \neq}$, \\ Mark A. Bradford ${ }^{5}$, Sabrina Carvalho ${ }^{1}$, Gerlinde B. De Deyn ${ }^{6}$, Franciska T. de Vries ${ }^{3,7}$, \\ Ken E. Giller ${ }^{8}$, David Kleijn ${ }^{9}$, Douglas A. Landis ${ }^{10}$, Walter A. H. Rossing ${ }^{11}$, \\ Maarten Schrama ${ }^{12}$, Johan Six ${ }^{2}$, Paul C. Struik ${ }^{13}$, Stijn van Gils ${ }^{1}$, \\ Johannes S. C. Wiskerke ${ }^{14}$, Wim H. van der Putten ${ }^{1,15}$ and Louise E. M. Vet ${ }^{1,16}$ \\ ${ }^{1}$ Department of Terrestrial Ecology, Netherlands Institute of Ecology (NIOO-KNAW), Wageningen, Netherlands, ${ }^{2}$ Sustainable \\ Agroecosystems, Department of Environmental Systems Science, Institute of Agricultural Sciences, ETH Zurich, Zurich, \\ Switzerland, ${ }^{3}$ School of Earth and Environmental Sciences, The University of Manchester, Manchester, United Kingdom, \\ ${ }^{4}$ World Agroforestry Centre (ICRAF), Nairobi, Kenya, ${ }^{5}$ School of Forestry and Environmental Studies, Yale University, \\ New Haven, CT, United States, ${ }^{6}$ Soil Biology Group, Wageningen University, Wageningen, Netherlands, ${ }^{7}$ Department of \\ Ecosystem and Landscape Dynamics (IBED-ELD), Institute of Biodiversity and Ecosystem Dynamics, University of \\ Amsterdam, Amsterdam, Netherlands, ${ }^{8}$ Plant Production Systems, Wageningen University, Wageningen, Netherlands, \\ ${ }^{9}$ Plant Ecology and Nature Conservation Group, Wageningen University, Wageningen, Netherlands, ${ }^{10}$ Department of \\ Entomology and Great Lakes Bioenergy Research Center, 204 CIPS, Michigan State University, East Lansing, MI, \\ United States, ${ }^{11}$ Farming Systems Ecology, Wageningen University and Research, Wageningen, Netherlands, ${ }^{12}$ Department \\ of Environmental Biology, Institute of Environmental Sciences, Leiden University, Leiden, Netherlands, ${ }^{13}$ Centre for Crop \\ Systems Analysis, Wageningen University and Research, Wageningen, Netherlands, ${ }^{14}$ Rural Sociology Group, Wageningen \\ University, Wageningen, Netherlands, ${ }^{15}$ Laboratory of Nematology, Wageningen University, Wageningen, Netherlands, \\ ${ }^{16}$ Laboratory of Entomology, Wageningen University, Wageningen, Netherlands
}

Interactions between aboveground and belowground organisms are important drivers of plant growth and performance in natural ecosystems. Making practical use of such above-belowground biotic interactions offers important opportunities for enhancing the sustainability of agriculture, as it could favor crop growth, nutrient supply, and defense against biotic and abiotic stresses. However, the operation of above- and belowground organisms at different spatial and temporal scales provides important challenges for application in agriculture. Aboveground organisms, such as herbivores and pollinators, operate at spatial scales that exceed individual fields and are highly variable in abundance within growing seasons. In contrast, pathogenic, symbiotic, and decomposer soil biota operate at more localized spatial scales from individual plants to patches of square meters, however, they generate legacy effects on plant performance that may last from single to multiple years. The challenge is to promote pollinators and suppress pests at the landscape and field scale, while creating positive legacy effects of local plant-soil interactions for next generations of plants. Here, we explore the possibilities to improve utilization of above-belowground interactions in agro-ecosystems by considering spatio-temporal scales at which aboveground and belowground organisms operate. We identified that successful integration of above-belowground biotic interactions initially requires developing crop rotations and intercropping systems that create positive local soil legacy effects for neighboring as 
well subsequent crops. These configurations may then be used as building blocks to design landscapes that accommodate beneficial aboveground communities with respect to their required resources. For successful adoption of above-belowground interactions in agriculture there is a need for context-specific solutions, as well as sound socio-economic embedding.

Keywords: above-belowground biotic interactions, sustainable agriculture, spatio-temporal scales, agroecology, steering communities

\section{INTRODUCTION}

The pressure on agricultural and natural resources is increasing due to human population growth, ongoing urbanization, climate change, and the growing demand for bio-based products. Given that the world population is expected to increase up to 11 billion people during the 21st century, a key question for society is how to meet the growing demands for food, feed, biomass, and other ecosystem services sustainably (Godfray et al., 2010; Rockström et al., 2017). Achieving global food security in the coming decades will require major changes in the whole food system, including food consumption patterns, waste management, and the food provision chain (Godfray et al., 2010), as well as a redesign of agricultural systems (Pretty et al., 2018).

Current agricultural systems produce food and feed at high levels of efficiency, but often require large inputs of external resources, which can have strong negative impacts on the environment (Pretty, 2018). For example, in highinput production systems considerable leaching of nutrients into ground and surface water, emission of greenhouse gases into the atmosphere, and loss of biodiversity from intensive agricultural landscapes have been reported (Matson et al., 1997; Hallmann et al., 2017; Rockström et al., 2017). It has long been recognized that the use of ecological principles in agro-ecosystems can benefit crop productivity (de Wit, 1960; Dore et al., 2011). Still, further integration of ecological knowledge into agriculture may offer important opportunities for enhancing sustainability (Tittonell, 2014; Struik and Kuyper, 2017) by balancing crop production with other ecosystem functions, such as retention of nutrients and natural control of pests and diseases (Bommarco et al., 2013; Pretty et al., 2018).

For at least the last three decades ecologists have acknowledged that understanding plant growth and performance requires integration of both aboveground and belowground biotic interactions (Brown and Gange, 1990; Wardle et al., 2004; van Dam and Heil, 2011). However, the research field on "aboveground-belowground interactions" has developed primarily in natural systems. It has been suggested that integrating this knowledge into agriculture offers possibilities for aiding sustainable crop production (van der Putten et al., 2009; Orrell and Bennett, 2013; Pineda et al., 2017) and for ecosystem service provision (A'Bear et al., 2014), but thus far relatively little progress has been made in applying this concept in production systems. One key aspect that might complicate reliable application in agriculture or horticulture is the vastly different spatial and temporal scales at which aboveground-belowground biotic interactions operate (Bardgett et al., 2005; van der Putten et al., 2009; Bommarco et al., 2013). Information on appropriate spatio-temporal scales is crucial for effectively rolling out policies into management practices (Kleijn et al., 2018a).

In the current paper we make the next step toward integrating above-belowground interactions in ecosystems by pointing at the different scales at which belowground vs. aboveground interactions are being influenced by the surrounding environment. We use current ecological knowledge to explore how above-belowground biotic interactions can be used to benefit pollination, pest and pathogen control, crop production, soil carbon and nutrient cycling, and other ecosystem services in agro-ecosystems. We explicitly consider the spatio-temporal scales at which aboveground and belowground organisms operate and propose how this could help to redesign current agricultural landscapes. We identify research priorities and discuss the need of good socio-economic guidance for further integration of above-belowground interactions in a more ecological, or nature-inclusive, agricultural practice.

\section{ABOVE- AND BELOWGROUND BIOTIC COMMUNITIES}

\section{Aboveground Biotic Communities}

Aboveground, crops are affected by both beneficial and antagonistic organisms, which impacts the economics of farming practices (Losey and Vaughan, 2006; Gallai et al., 2009; Holland et al., 2016). Crops are under attack of herbivores and foliar pathogens, while benefitting from pollination by insects. In agricultural fields, wild insects, such as bees and hoverflies, account for up to half of all flower visits of various important crops and lead to substantial yield increases (Garibaldi et al., 2013). At the same time crops benefit from indirect defense by insects parasitizing and predating on herbivorous natural enemies. Biological control of specific pests has been implemented for a long time in greenhouses, orchards, and arable crops (van Lenteren, 2012), but also through stimulation of natural insect populations (Landis et al., 2000; Tscharntke et al., 2005; Gurr et al., 2016; Rusch et al., 2016). The complexity of interactions in the field is substantially greater than in closed production systems such as greenhouses, because pollinators and enemies move around the agricultural landscape where they use a variety of resources both on and off the cropping field at different points in time. Such conditions generally are not present in more closed systems, such as in greenhouses. 
The spatial organization of landscapes has been shown to strongly affect aboveground biotic interactions. For arable cropping systems, semi-natural habitats are crucial for the persistence of populations of pollinators and natural enemies (Steffan-Dewenter et al., 2002; Kennedy et al., 2013; Barrios et al., 2018; Karp et al., 2018). Pollinators are largely dependent on semi-natural habitats outside agricultural fields for provision of alternative food resources and nesting sites (Kleijn et al., $2018 b$ ). Both abundance and species diversity of pollinators increases with an increasing percentage of semi-natural habitat in the surrounding $0.5-3 \mathrm{~km}$ (Steffan-Dewenter et al., 2002; Kennedy et al., 2013). At the same time, semi-natural habitats, such as flower strips, hedgerows and forest patches, provide habitat or alternative resources for both herbivores and their natural enemies (Landis et al., 2000). Most studies show that increases in the percentage of semi-natural habitat in agricultural landscapes enhance biocontrol by reducing pest abundance (Shackelford et al., 2013; Veres et al., 2013). Recent research indicates that not only the amount of semi-natural habitat, but also its spatial configuration strongly determines the degree of pollination and pest control (Tscharntke et al., 2005; Rusch et al., 2016; Baillod et al., 2017). Consequently, the spatial ecology of the aboveground community is a crucial factor that should be considered when designing agricultural landscapes and intercropping systems (Allema et al., 2014).

Next to spatial optimization, efficient pollination and pest control will further require that the relevant invertebrate populations, or the function that they have, can be maintained through time. An important prerequisite for this is that the arable fields and the surrounding landscape together provide resource continuity through the year (Schellhorn et al., 2015). For example, Riedinger et al. (2013) show that flower visitation by bumblebees in late-flowering sunflower fields was significantly enhanced in landscapes with high cover of early-flowering oilseed rape crops. Crops with a later phenology that use the same pollinators may then benefit from the legacies of earlier crops. Currently, efforts are already made to "tailor" the characteristics of both the cropped fields and the surrounding area toward optimizing resource continuity for natural enemies of pests (Holland et al., 2016). However, this practice needs to be applied more regularly and needs to integrate temporal legacy effects of aboveground ecosystem services such as pollination and pest control and their high temporal turnover.

\section{Belowground Biotic Communities}

Soil organisms can have substantial effects on crop growth and health. For example, belowground pests and pathogens can cause major crop losses (Haas and Défago, 2005), while (symbiotic) mutualists, such as diazotrophic bacteria $\left(\mathrm{N}_{2}\right.$-fixers; Canfield et al., 2010), arbuscular mycorrhizal fungi (van der Heijden and Hartmann, 2016; Bowles et al., 2017) and plant growth-promoting rhizobacteria (Lugtenberg and Kamilova, 2009; Raaijmakers et al., 2009) can enhance plant resource uptake and stimulate plant growth and nutrition, as well as resistance to stress and pests (Raaijmakers et al., 2009; Yang et al., 2009). Further, heterotrophic fungal and bacterial communities play a key role in the decomposition of organic matter and transformation of soil nutrients and may contribute to pest control or enhance plant tolerance thereby influencing plant nutrition and growth (Wardle et al., 2004; Raaijmakers and Mazzola, 2016).

Plant species cultivate specific soil communities (Raaijmakers et al., 2009) which can persist in the soil as legacy effects that in turn influence the growth of plants in next generations (also termed "plant-soil feedback") (Bever et al., 2010; Wubs and Bezemer, 2018), and/or of neighboring plants (Kos et al., 2014). These effects can be mediated by living plant roots, as well as by plant litter inputs, because plant-specific decomposer communities might specialize in breaking down organic substrates from the plants they are associated with (Rashid et al., 2013; Veen et al., 2015). Specific decomposers may accelerate soil nutrient cycling and thereby potentially favor plant species future growth. Although most soil biotic legacy effects are highly localized, they can persist in the soil for years and even up to decades (Wubs et al., 2019) and as a result have a major impact on future plant growth and dynamics, as well as on carbon and nutrient cycling in the entire ecosystem.

The spatial extent of soil legacy effects depends strongly on the spatial configuration of plant species and varies at scales ranging from individual plants to plant patches, both in natural habitats (Ettema and Wardle, 2002; Bardgett et al., 2005) and in crop fields (Haas and Défago, 2005). The magnitude and direction of temporal legacy effects also strongly depend on the plant growth form (Kardol et al., 2006; Cortois et al., 2016) and competitive or facilitative interactions with neighboring plants (Casper and Castelli, 2007; Müller et al., 2016). For example, early-successional wild plant species, which have an ecology comparable to the ancestors of crop species, often build up negative soil legacy effects that reduce subsequent growth of plants and accelerate plant succession (Kardol et al., 2006). Wild species cope with such negative feedback effects via cyclic dynamics in plant community composition, a model underpinning crop rotation (Mariotte et al., 2018). Negative feedbacks may also control spatial diversity in the plant community, and this knowledge may be used to enhance the efficiency of intercropping systems (Zhang and Li, 2003; Barel et al., 2018). A key challenge is to develop intercropping and crop rotation systems that optimally use positive and avoid negative plant-induced legacy effects (Mariotte et al., 2018).

\section{Above-Belowground Biotic Interactions}

In both natural and agricultural ecosystems, aboveground and belowground communities do not only affect plants, but via plants they also influence each other (Bardgett and Wardle, 2010). These interactions can be mediated by many different components of the biotic community, including, aboveand belowground herbivores and pathogens, aboveground parasitoids and pollinators, and belowground mutualists, and decomposer organisms (A'Bear et al., 2014; Heinen et al., 2018). Such aboveground-belowground interactions can be mediated via changes in plant primary and secondary chemistry (van der Putten et al., 2001; Kostenko et al., 2012) and play an important role in driving the functioning of ecological communities (Bardgett and Wardle, 2010). For example, belowground 
herbivores and pathogens may prime or reduce parasitoid or pollinator attraction by modifying plant volatile emissions or shoot tissue quality (Lucas-Barbosa et al., 2011; Soler et al., 2012). In turn, aboveground herbivores may stimulate root exudation, which can increase the activity of the soil community and thereby ecosystem processes such as carbon and nitrogen cycling (Bardgett and Wardle, 2003). Also, soil decomposers may enhance plant productivity and quality via enhanced nutrient cycling, which can both increase susceptibility to pests and herbivory via increased food quality or decrease herbivore performance via increased levels of secondary metabolites (A'Bear et al., 2014).

In agro-ecosystems, above-belowground interactions can be used to improve sustainable crop production (Orrell and Bennett, 2013; Tamburini et al., 2016), because these interactions may optimize ecosystem services such as biological control of herbivore populations by natural enemies, pollination, and soil nutrient cycling (A'Bear et al., 2014; Pineda et al., 2017). For example, arbuscular mycorrhizal fungi, growth-promoting rhizobacteria, and earthworms can improve plant nutrition and hence prime plant defenses to above- or belowground pests or can enhance the attraction of pollinators (Gange and Smith, 2005; van Groenigen et al., 2014). Managing networks of abovebelowground interactions has the potential to simultaneously improve plant nutrition, resistance to pathogens, and benefits from mutualists (Orrell and Bennett, 2013; Mariotte et al., 2018).

Utilizing above-belowground interactions for agroecosystems requires unraveling the spatio-temporal scales at which the key players in complex agro-ecological networks operate and affect each other (Bommarco et al., 2013). Aboveground pollinator and pest communities operate on a field or landscape spatial scale and are not restricted to interactions with individual plants (Figure 1). In contrast, plant-soil interactions often play out at much finer spatial scale of an individual root or plant (Ettema and Wardle, 2002), and have long-lasting legacy effects (Wubs et al., 2019), e.g., because many soil-borne organisms have persistent "dormant" stages (Lennon and Jones, 2011). Complex network interactions of antagonists and symbiotic mutualists in the soil will then influence subsequent plant growth and performance highly locally (Raaijmakers and Mazzola, 2016; van der Heijden and Hartmann, 2016). A major challenge for applying the aboveground-belowground interaction concept in agriculture will be to integrate management of pests, pollinators, and crop diversity at the landscape and field scale with local plant-soil interactions at the level of individual plants or plant patches (Figure 1).

Identifying combinations of above-belowground biotic interactions that positively feed back to crop growth and ecosystem functioning in space and time will be essential in order to utilize these interactions for sustainable agriculture (Figure 2). By using new analytical approaches we can quantify above-belowground interactions from a network perspective (van der Heijden and Hartmann, 2016; Ramirez et al., 2018), and connect network characteristics to functional properties (Morriën et al., 2017). Currently progress is made on research on whole phytobiomes (Leach et al., 2017; Sánchez-Cañizares et al.,
2017), i.e., all aboveground and belowground taxa associated with plants, to capture the complexity and unravel the web of interactions between them (Ledford, 2015). This will help to identify the combinations of above-belowground interactions that may aid future sustainable agriculture.

\section{RESEARCH PRIORITIES AND IMPLICATIONS FOR REDESIGNING AGROECOSYSTEMS}

\section{Steering Aboveground Communities}

Increasingly, knowledge of aboveground spatial and temporal dynamics is being used to design agricultural landscapes to enhance multiple ecosystem services (Schellhorn et al., 2015; Landis, 2017). Concrete steps that farmers and researchers may take to enhance and optimize ecosystem services include considerations of field size and shape, the inclusion of intentionally managed non-crop habitats and crop spatiotemporal diversity. To increase functional biodiversity in agricultural landscapes smaller field sizes need to be maintained or created (Fahrig et al., 2015). Modeling studies suggest that dispersed rather than aggregated distribution of conservation habitats is likely to yield greater ecosystem services in agricultural landscapes (Cong et al., 2016), although large contiguous reserves will still be required to safeguard most other biodiversity. Where semi-natural habitats are lacking, adding designed habitats can provide beneficial organisms with shelter, floral resources, and alternate prey (Landis et al., 2000; Gurr et al., 2017). Finally, harvesting crops in sequence and having sufficient off-field resources when crops are not available will provide resource continuity through the year to maintain aboveground invertebrate populations (Schellhorn et al., 2015).

For pollinators, both the composition and configuration of crop and non-crop habitats is important to maintain effective communities (Barrios et al., 2018; Hass et al., 2018). Practices that increase flower-rich habitats can enhance pollinator conservation at the farm and landscape level (Dicks et al., 2015; Holland et al., 2015; Kleijn et al., 2018b). For example, targeted wildflower plantings increased pollinator abundance in an adjacent pollinationdependent crop, increasing yields, and repaying the cost of floral installation in 3-4 years (Blaauw and Isaacs, 2014). Also, new studies show that in combination with the presence of floral resources, adding artificial nesting sites can increase abundance of aboveground nesting wild bees (Dainese et al., 2018).

Natural enemies also respond to landscape and local habitat structure in ways that influence pest suppression services (Bianchi et al., 2006). In general, as landscape complexity and the amount of non-crop habitat increase, the abundance and diversity of natural enemies and pest suppression may also increase (Chaplin-Kramer et al., 2011; Shackelford et al., 2013; Veres et al., 2013), but effects can be inconsistent (Barrios et al., 2018; Karp et al., 2018). Targeted interventions to specifically create and manage habitats that enhance natural enemies and pest suppression is promising (Gurr et al., 2017). For example, 


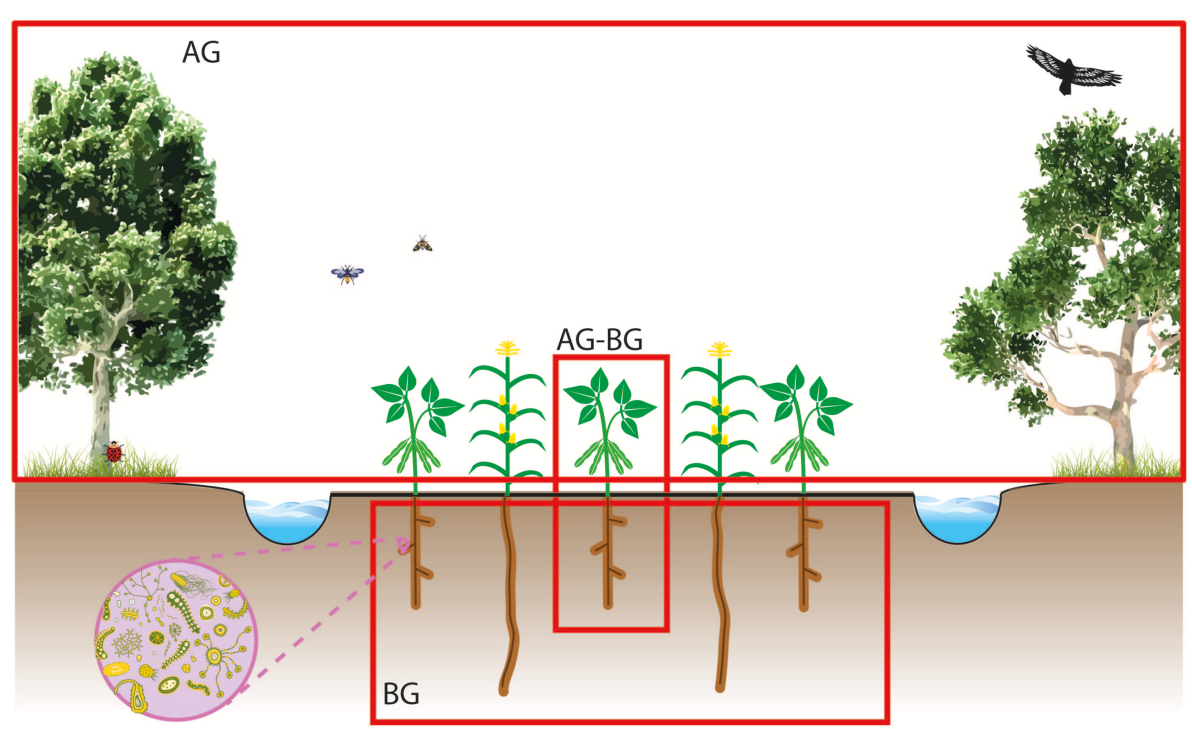

FIGURE 1 | Figure showing the scale of current aboveground (AG), belowground, (BG) and AG-BG knowledge.

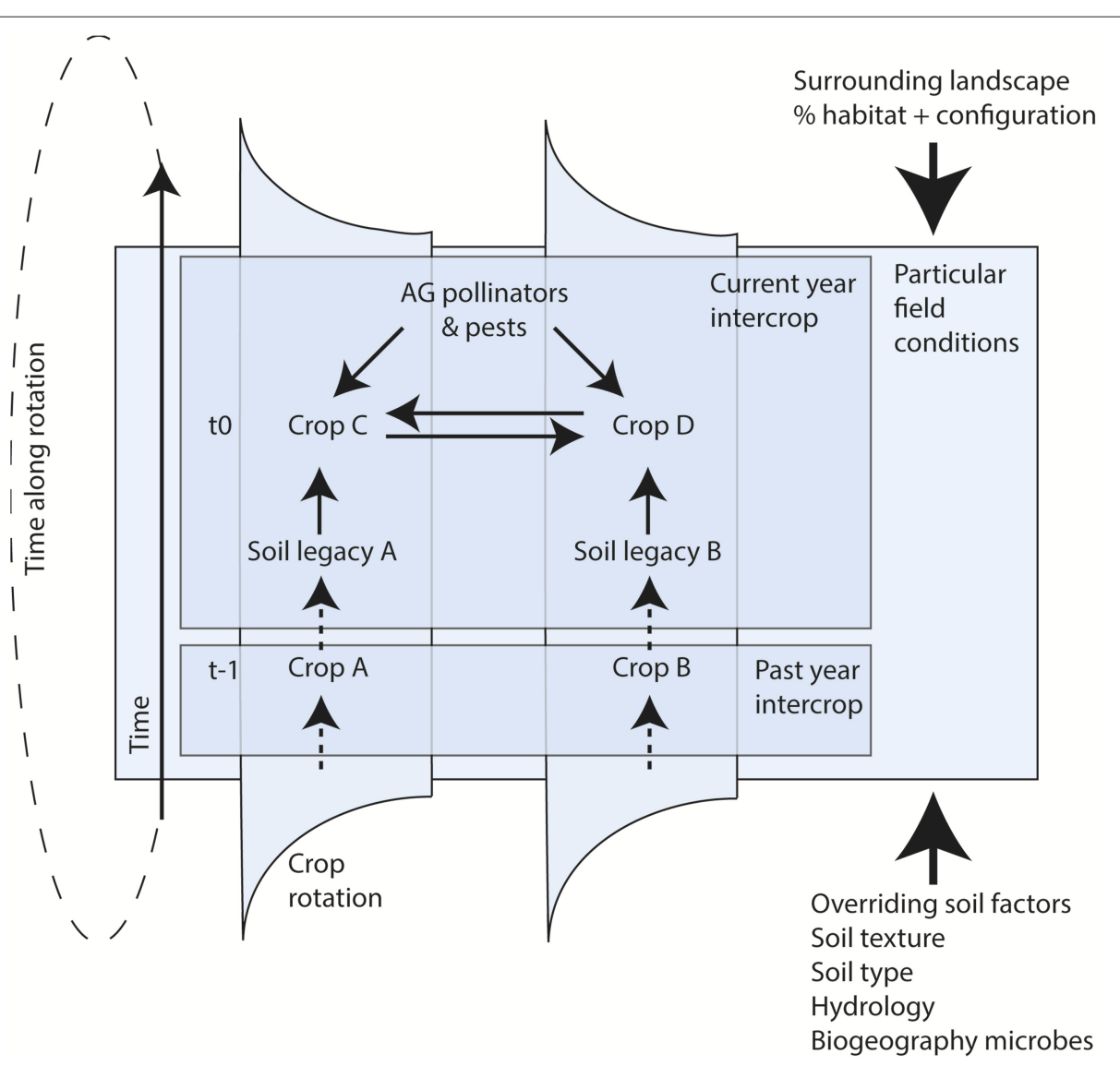

FIGURE 2 | Conceptual diagram of AG-BG interactions. Shown is part of a crop rotation with alternating intercrops along a multi-stage sequence (may include cover crops). Solid arrows indicate factors that influence crop yields in the present year, dashed arrows indicate past effects. The thick solid arrows indicate the influence of overriding factors. The previous years' intercrop has created soil legacies (A \& B) which may impact the growth of both concurrent crops (C \& D). In addition, soil legacies may affect presence and impact of AG pollinators and pests (indirect effect of legacy $\mathrm{A}$ on $\mathrm{C}$ or also on D). The conditions in the field will largely be determined by overriding landscape and soil factors, which will modify the outcomes of the AG-BG interactions in the focal field. 
natural enemy abundance and diversity generally increase in wildflower plantings adjacent to agricultural fields (Morandin et al., 2014; Blaauw and Isaacs, 2015; Tschumi et al., 2016b), and their spillover into adjacent crops can increase yields (Tschumi et al., 2016a). Also, smaller field sizes can suppress the abundance of pests via increasing spatial diversity (Baillod et al., 2017). Finally, at the scale of individual plants, the colonization of foliar diseases may be prevented by optimizing the aboveground microbiome composition on plants, i.e., in the phyllosphere, (Ritpitakphong et al., 2016), but how this works out in practice and across whole fields is still unknown.

\section{Steering Soil Communities}

Manipulating soil communities via the legacies that crop species leave behind belowground may be mediated via the identity, functional traits and diversity of crop species (e.g., via intercropping). Legacy effects should be optimized for nutrient cycling, beneficial interactions between plants, and soil biota and disease suppression (Brooker et al., 2015; Dias et al., 2015; Mariotte et al., 2018). Considering all these different types of legacy effects is novel when compared to traditional crop rotation, which was strongly focusing on suppressing crop species-specific soil-borne diseases. The particular sequence of plants growing in the soil will determine subsequent legacy effects (Wubs and Bezemer, 2018) and plant root traits may provide a way to predict beneficial sequences of plant species (Bardgett et al., 2014; Cortois et al., 2016). In addition, repeated application of organic substrates can have a strong positive influence on the capacity of decomposer communities to recycle nutrients (Rashid et al., 2013; Hartmann et al., 2015; Martínez-García et al., 2018), offering the potential to steer soil communities to benefit plant growth and nutrition. Moreover, increased levels of soil organic matter can suppress soil-borne diseases (Bonanomi et al., 2010; Korthals et al., 2014).

Soil communities can also be steered via direct inoculation of soils with microbial strains or communities. Inoculation with strains that benefit plant growth and nutrition, such as specific strains of arbuscular mycorrhizae, may boost plant nutrition (Adam et al., 2016). Microbial inoculations are generally successful in experimental settings, but single-strain inoculations often work less well in large-scale agriculture because of competition by the resident soil community (Raaijmakers and Mazzola, 2016). Diverse microbial communities are often resistant to invasion and establishment of new species due to a lack of available ("empty") niches (Mallon et al., 2015). Therefore, inoculation of strains of soil microbes may aid crop growth most likely in highly controlled environments, such as greenhouses, where competition of the existing microbial community can be controlled, but less well in the field. In field soil it may be necessary to introduce microbial strains together with biotic or abiotic environmental disturbances to create empty niches in the existing community and to allow establishment of new strains (Adam et al., 2016). It is possible that targeted engineering of the host microbiome can help to steer beneficial plant-soil interactions for agriculture (Oyserman et al., 2018).

Inoculation studies in the context of nature restoration have shown that whole-soil inocula, which include intact microbial communities, outperform inocula of individual mycorrhizal strains (Rowe et al., 2007; Emam, 2016). For example relatively small whole-soil inocula $(150 \mathrm{ml})$ into $0.25 \mathrm{~m}^{2}$ plots promoted plant performance within a $2 \mathrm{~m}$ radius from the inoculation in just two growing seasons (Middleton and Bever, 2012). On a larger scale $\left(\geq 1,000 \mathrm{~m}^{2}\right)$, soil inoculations have successfully influenced plant performance and composition in natural systems by steering soil community composition into different developmental trajectories (Wubs et al., 2016). In that study, also soil inoculation worked better in subsoil than in intact topsoil. Based on these findings, it seems promising to focus on field-scale inoculation of whole microbial communities in agroecosystems, but it is important to determine the conduciveness of the existing soil community for uptake of the inoculum. It will be necessary to set up field trials, to be able to investigate the optimal spatial and temporal scales of soil inoculation, and to find out how soil inoculation should be integrated into crop rotation schemes and can be combined with high-tech management tools and precision farming. Such efforts should go hand-inhand with breeding programs for optimal plant-microbiome interactions (Raaijmakers and Mazzola, 2016) and engineering of plant microbiomes (Oyserman et al., 2018).

\section{Steering Above-Belowground Interactions}

Management tools are mostly directed toward steering either aboveground or belowground biotic communities. A key future challenge will be to integrate these tools and jointly steer above-belowground interactions for positive plant, field- and landscape-scale feedbacks (Figure 2). As belowground processes are local and can last for long periods of time, we propose to take these processes as a starting point for steering abovebelowground interactions. It will be essential to design spatiotemporal configurations of crops by combining principles from crop rotation and intercropping (Brooker et al., 2015; Dias et al., 2015; Mariotte et al., 2018) to maximize the benefit of soil legacy effects on both neighboring and follow-up crops (Barel et al., 2018; Ingerslew and Kaplan, 2018; Figure 2). Whereas intercropping itself may yield higher crop biomass via enhanced nutrient uptake or reduced disease spread (Brooker et al., 2015), rotating intercrops designed to maximally benefit from belowground legacy effects can further enhance crop production (Figure 2). The mechanisms by which intercrops benefit crop growth will determine the spatial scale of intercropping; where crops interacting via more efficient resource use will need to grow in closer proximity (e.g., rows) than crops that primarily function to prevent the spread of diseases (e.g., strips or mixed monocropping; Brooker et al., 2015). Finally, optimal intercroprotation systems may include specific organic amendments and inoculations to steer specialized soil communities in the rotation sequence. Optimal intercrop-rotations can then be used as building blocks to redesign agricultural landscapes for steering aboveground processes, such as pollination, avoidance of aboveground diseases and stimulation of natural enemies, taking field size and shape, and the amount and configuration of natural habitats into account (Tscharntke et al., 2005; Baillod et al., 2017).

To implement intercropping and crop rotation in an optimal above-belowground context requires targeted screening 
of combinations of crops and above-belowground processes that drive positive plant, field-, and landscape-scale feedbacks. Adopting a functional-trait based approach will provide a valuable framework for getting a mechanistic understanding of how inter- and intraspecific combinations of crop species link to ecosystem functioning (Bardgett et al., 2014; Ke et al., 2015; Martin and Isaac, 2015). Screening needs to be done at scales relevant to farmers and should take taking local abiotic and biotic soil conditions into consideration in order to obtain knowledge about how integrating abovebelowground interactions into agricultural management impacts both ecosystem functioning and profit for farmers (Kleijn et al., 2018a). In addition, to determine the spatial extent and consequences of plant-induced soil legacy effects in agricultural settings will require using a spatially-explicit approach in belowground agro-ecology (see Quist et al., 2017; Schrama et al., 2018). Further, testing interactions between crops and above-belowground interactions across realistic above- and belowground spatiotemporal dimensions can be explored using process- or individual-based models (van der Putten et al., 2009; Evers et al., 2018). Differences in mobility and dispersal of organisms living above- or belowground can be represented more easily in such models than in field experiments.

\section{CONTEXT-DEPENDENCY}

\section{Environmental Context}

Although above-belowground biotic interactions have a strong potential to aid sustainable agriculture, the ecological context in which they operate varies strongly across the globe and this can alter how they drive crop growth and ecosystem functioning (Agrawal et al., 2007; Pittelkow et al., 2015; Karp et al., 2018; Figure 2). The impact of soil legacies on plants is strongly dependent on climatic conditions (De Long et al., 2018), as well as biotic and abiotic environmental conditions (Bezemer et al., 2006; Casper and Castelli, 2007; Ke et al., 2015). For example, the magnitude and direction of plant growth responses to soil legacy effects can be modified by soil texture or chemistry (Bezemer et al., 2006). Similarly, the diversity of aboveground predator and parasitic insects varies along environmental gradients of temperature and habitat diversity (Corcos et al., 2018). These examples highlight that it is crucial to find site-specific solutions when implementing ecological processes in agriculture (Reynolds et al., 2014; Tittonell, 2014; Tittonell et al., 2016) and that we thus need a thorough understanding of the context-dependency of these processes.

To investigate context-specific solutions, we can use state-ofthe-art structural equation modeling approaches to disentangle multiple causal pathways (Grace et al., 2012; Shipley, 2016). For a thorough understanding it is essential to combine data on crop performance (quantity and quality) across a wide range of environmental contexts (Cui et al., 2018). Data from dynamic, cloud-based databases can be used and connected to researchers and farmers, such as through the use of Resource Watch (http:// resourcewatch.org/). In such databases information should be collected on results of management practices on the scale of individual farms and landscapes (e.g., yields, disease, and pollution) across the globe (e.g., Jones et al., 2018). Using mobile phone apps, individual farmers can contribute their information on management and yields directly. Such a system is already operative in a micro-insurance network of African farmers, where high spatial resolution weather data are coupled with crop failure claims submitted by individual smallholder farmers (Acre Africa, http://acreafrica.com/). Also, smallholder farmers, connected through their mobile phones, can now exchange solutions for specific farming problems within a global network (WeFarm, http://wefarm.org/). Big data sharing technology and the use of open datasets are rapidly expanding (Culina et al., 2018) and will allow the inclusion of many more relevant parameters, across a range of scales, resulting in a wealth of data that allow efficient searches for the optimal response to environmental conditions (by coupling climate, soil, hydrology, epidemiology etc. data and models). The open nature of these databases and tools mean they can be provided for free to the participating farmers allowing these solutions to be improved iteratively. Naturally, big data approaches should not interfere with testing novel management practices as big data can only be used to optimize existing practices.

\section{Socio-Economic Context}

It is possible to arrive at the better solutions in agro-ecological terms (e.g., yield, nutrient losses, greenhouse gas emissions etc.); however, it is also critically important to study the socioeconomic feasibility and the policy changes needed to facilitate the transition. First of all, successful adoption of ecological principles in agriculture will depend to a large extent on the behavior of people (Cinner, 2018). In addition, it is critically dependent on the economic benefit for farmers, and those benefits need to be expressed at spatio-temporal scales relevant to farmers (Kleijn et al., 2018a). Moreover, all changes challenge, at least to some extent, the "normal" way of doing things (Magrini et al., 2016). This "normal" way, also denoted as the sociotechnical regime, is a coherent set of social and technological elements that underpins basic societal functions (Holtz et al., 2008). For agro-ecological systems, some innovations may be easy to incorporate on-farm or elsewhere in the food system as they complement already existing practices and norms. Other innovations may require fundamental changes in farming practices, food systems, payment schemes, and/or agro-food policies to be implemented.

Application of inoculants, for instance, may be part of incremental innovations, while more radical ideas (named sharpkey approaches), such as intercropping with a range of different crop species to support above-belowground biotic interactions or combining whole-field soil inoculations with high-tech farming solutions may lead to and require a disruptive change of the socio-technical regime. More radical changes may encompass bio-technical aspects, such as development of cultivars that constitute good companions in mixtures (Zuppinger-Dingley et al., 2014), integrating management for above-belowground interactions into precision farming, or processing of more diverse products in the food industry. In addition, it will also include administrative procedures (e.g., what constitutes a field under strip cropping conditions, what is the legal status of applied 
inocula), and explicit and implicit rules in economic transactions, e.g., concerning purity of product, added value of diversification for consumers, and patentability of products.

Applying ecological principles to agriculture calls for coupled innovations (Roep et al., 2003; Wiskerke and Van der Ploeg, 2004; Rasmussen et al., 2018), where changes are not only made in the bio-technical domain, but also in the economic, administrative and innovation support domains (Tittonell et al., 2016; Meynard et al., 2017). Such reconfiguration of food systems is not only complicated in itself; it is also complex because multiple societal actors are involved, which results in feedbacks that create unexpected emergent societal dynamics. At the same time, the most positive social-ecological outcomes of applying ecological principles are achieved when landscape restoration and diversification of agronomic practices are combined (Rasmussen et al., 2018). Together, this suggests that successful redesign of agricultural systems will require a multiscale and multi-stakeholder approach (Jordan and Warner, 2010; Kessler et al., 2016; Struik and Kuyper, 2017). Close, on-site and hands-on collaboration between farmers, ecologists, consumers, civil society organizations, and agro-food businesses, in "livinglabs," in a learning by doing context, will not only build mutual understanding and trust, but will also significantly enhance the co-production and sharing of applied ecological knowledge and speed up agricultural innovation processes. Research to support agro-ecological changes requires flexibility to adjust research questions in response to emerging demands, capabilities to communicate results in a timely and understandable manner (Clark et al., 2016), and a fundamental change of existing political and economic frameworks that impact on both the dynamics of agro-ecological systems and funding for research on agro-ecology.

\section{CONCLUSION}

We argue that applying ecological principles to agriculture requires an aboveground-belowground approach with explicit consideration and integration of the spatio-temporal scales of operation of above- and belowground processes. Knowledge from natural systems provides the basis to further the integration of an above-belowground approach for sustainable agriculture. A key innovation will be to use optimal intercroprotation combinations in spatio-temporal configurations that allow for steering above-belowground interactions. This should be done in such a way that these interactions result in positive plant, field- and landscape-scale feedbacks. The highly localized and long-term nature of soil-borne legacies suggests that rotating intercrops with positive plant-soil interactions need to be used as building blocks within the agricultural landscape. The spatio-temporal placement of these blocks should

\section{REFERENCES}

A'Bear, A., Johnson, S., and Jones, T. (2014). Putting the 'upstairs-downstairs' into ecosystem service: what can aboveground-belowground ecology tell us? Biol. Control 75, 97-107. doi: 10.1016/j.biocontrol.2013.10.004 then be designed to yield positive crop-landscape feedbacks accommodating the mobile and dynamic nature of aboveground communities. A key research priority will be to design optimal intercrop-rotation combinations and determine the spatiotemporal scales at which targeted management should be applied. To develop management and crops that are tailormade for specific environmental contexts, it will be crucial to integrate local knowledge and experience in global open source databases of agro-ecological technologies and their efficacy across environmental conditions. Finally, successful adoption of integrated above-belowground biotic approaches in agriculture requires adequate consideration of the enabling environment shaped by social, governance, and economic factors along the transition toward sustainable food and agricultural systems. We see a new role for ecologists to initiate the necessary interdisciplinary and cross-societal coalitions needed to reach this goal.

\section{AUTHOR CONTRIBUTIONS}

GV, EW, WvdP, and LV have written the paper. All authors have contributed to developing the ideas in this paper, reviewed, and commented on, several earlier drafts of the manuscript.

\section{FUNDING}

The conference and workshop where the ideas in this paper were developed were funded by a KNAW-grant (Over Grenzen) to LEMV. GV was funded by a NWO-VENI grant (No. 863.14.013). EW was funded by a NWO-RUBICON grant (No. 019.181EN.01). GD was supported by NWO-ALW VIDI grant (No. 864.11.003). Support for DL was provided by the U.S. Department of Energy, Office of Science, Office of Biological and Environmental Research (Awards DESC0018409 and DE-FC02-07ER64494), by the National Science Foundation Long-term Ecological Research Program (DEB 1637653) at the Kellogg Biological Station, and by Michigan State University AgBioResearch. WR received funding from the European Union's Seventh Framework Programme for research, technological development and demonstration under grant agreement No. 311879 (QUESSA-Quantification of ecological services for sustainable agriculture).

\section{ACKNOWLEDGMENTS}

This paper results from a conference and workshop organized by the Royal Netherlands Academy of Arts and Sciences (KNAW) and the Netherlands Institute of Ecology (NIOO-KNAW) in Amsterdam and Wageningen, the Netherlands.

Adam, E., Groenenboom, A. E., Kurm, V., Rajewska, M., Schmidt, R., Tyc, O., et al. (2016). Controlling the microbiome: microhabitat adjustments for successful biocontrol strategies in soil and human gut. Front. Microbiol. 7:1079. doi: 10.3389/fmicb.2016. 01079 
Agrawal, A. A., Ackerly, D. D., Adler, F., Arnold, A. E., Cáceres, C., Doak, D. F., et al. (2007). Filling key gaps in population and community ecology. Front. Ecol. Environ. 5, 145-152. doi: 10.1890/1540-9295(2007)5[145:FKGIPA]2.0.CO;2

Allema, B., van der Werf, W., van Lenteren, J. C., Hemerik, L., and Rossing, W. A. (2014). Movement behaviour of the carabid beetle Pterostichus melanarius in crops and at a habitat interface explains patterns of population redistribution in the field. PLoS ONE 9:e115751. doi: 10.1371/journal.pone.0115751

Baillod, A. B., Tscharntke, T., Clough, Y., and Batáry, P. (2017). Landscapescale interactions of spatial and temporal cropland heterogeneity drive biological control of cereal aphids. J. Appl. Ecol. 54, 1804-1813. doi: 10.1111/1365-2664.12910

Bardgett, R. D., Bowman, W. D., Kaufmann, R., and Schmidt, S. K. (2005). A temporal approach to linking aboveground and belowground ecology. Trends Ecol. Evol. 20, 634-641. doi: 10.1016/j.tree.2005.08.005

Bardgett, R. D., Mommer, L., and De Vries, F. T. (2014). Going underground: root traits as drivers of ecosystem processes. Trends Ecol. Evol. 29, 692-699. doi: 10.1016/j.tree.2014.10.006

Bardgett, R. D., and Wardle, D. A. (2003). Herbivore-mediated linkages between aboveground and belowground communities. Ecology 84, 2258-2268. doi: 10.1890/02-0274

Bardgett, R. D., and Wardle, D. A. (2010). Aboveground-Belowground Linkages. Biotic Interactions, Ecosystem Processes, and Global Change. Oxford: Oxford University Press.

Barel, J. M., Kuyper, T. W., de Boer, W., Douma, J. C., and De Deyn, G. B. (2018). Legacy effects of diversity in space and time driven by winter cover crop biomass and nitrogen concentration. J. Appl. Ecol. 55, 299-310. doi: 10.1111/1365-2664.12929

Barrios, E., Valencia, V., Jonsson, M., Brauman, A., Hairiah, K., Mortimer, P. E., et al. (2018). Contribution of trees to the conservation of biodiversity and ecosystem services in agricultural landscapes. Int. J. Biodivers. Sci. Ecosyst. Serv. Manag. 14, 1-16. doi: 10.1080/21513732.2017.1399167

Bever, J. D., Dickie, I. A., Facelli, E., Facelli, J. M., Klironomos, J., Moora, M., et al. (2010). Rooting theories of plant community ecology in microbial interactions. Trends Ecol. Evol. 25, 468-478. doi: 10.1016/j.tree.2010.05.004

Bezemer, T. M., Lawson, C. S., Hedlund, K., Edwards, A. R., Brook, A. J., Igual, J. M., et al. (2006). Plant species and functional group effects on abiotic and microbial soil properties and plant-soil feedback responses in two grasslands. J. Ecol. 94, 893-904. doi: 10.1111/j.1365-2745.2006.01158.x

Bianchi, F. J., Booij, C. J., and Tscharntke, T. (2006). Sustainable pest regulation in agricultural landscapes: a review on landscape composition, biodiversity and natural pest control. Proc. R. Soc. B. Biol. Sci. 273, 1715-1727 doi: $10.1098 / \mathrm{rspb} .2006 .3530$

Blaauw, B. R., and Isaacs, R. (2014). Flower plantings increase wild bee abundance and the pollination services provided to a pollination-dependent crop. J. Appl. Ecol. 51, 890-898. doi: 10.1111/1365-2664.12257

Blaauw, B. R., and Isaacs, R. (2015). Wildflower plantings enhance the abundance of natural enemies and their services in adjacent blueberry fields. Biol. Control 91, 94-103. doi: 10.1016/j.biocontrol.2015.08.003

Bommarco, R., Kleijn, D., and Potts, S. G. (2013). Ecological intensification: harnessing ecosystem services for food security. Trends Ecol. Evol. 28, 230-238. doi: 10.1016/j.tree.2012.10.012

Bonanomi, G., Antignani, V., Capodilupo, M., and Scala, F. (2010). Identifying the characteristics of organic soil amendments that suppress soilborne plant diseases. Soil Biol. Biochem. 42, 136-144. doi: 10.1016/j.soilbio.2009. 10.012

Bowles, T. M., Jackson, L. E., Loeher, M., and Cavagnaro, T. R. (2017). Ecological intensification and arbuscular mycorrhizas: a meta-analysis of tillage and cover crop effects. J. Appl. Ecol. 54, 1785-1793. doi: 10.1111/1365-2664.12815

Brooker, R. W., Bennett, A. E., Cong, W. F., Daniell, T. J., George, T. S., Hallett, P. D., et al. (2015). Improving intercropping: a synthesis of research in agronomy, plant physiology, and ecology. New Phytol. 206, 107-117. doi: $10.1111 /$ nph. 13132

Brown, V. K., and Gange, A. C. (1990). "Insect herbivory below ground," in Advances in Ecological Research, eds M. Begon, A. Fitter, and A. Macfadyen (Cambridge, MA: Academic Press), 1-58. doi: 10.1016/S0065-2504(08)60052-5

Canfield, D. E., Glazer, A. N., and Falkowski, P. G. (2010). The evolution and future of Earth's nitrogen cycle. Science 330, 192-196. doi: 10.1126/science.1186120
Casper, B. B., and Castelli, J. P. (2007). Evaluating plant-soil feedback together with competition in a serpentine grassland. Ecol. Lett. 10, 394-400. doi: 10.1111/j.1461-0248.2007.01030.x

Chaplin-Kramer, R., O'Rourke, M. E., Blitzer, E. J., Kremen, C., ChaplinKramer, R., O'Rourke, M. E., et al. (2011). A meta-analysis of crop pest and natural enemy response to landscape complexity. Ecol. Lett. 14, 922-932. doi: $10.1111 / \mathrm{j} .1461-0248.2011 .01642 . \mathrm{x}$

Cinner, J. (2018). How behavioral science can help conservation. Science 362, 889-890. doi: 10.1126/science.aau6028

Clark, W. C., van Kerkhoff, L., Lebel, L., Gallopin, G. C., Clark, W. C., van Kerkhoff, L., et al. (2016). Crafting usable knowledge for sustainable development. Proc. Natl. Acad. Sci. U.S.A. 113, 4570-4578 doi: 10.1073/pnas.1601266113

Cong, R.-G., Ekroos, J., Smith, H. G., and Brady, M. V. (2016). Optimizing intermediate ecosystem services in agriculture using rules based on landscape composition and configuration indices. Ecol. Econ. 128, 214-223. doi: 10.1016/j.ecolecon.2016.05.006

Corcos, D., Cerretti, P., Mei, M., Vigna Taglianti, A., Paniccia, D., Santoiemma, G., et al. (2018). Predator and parasitoid insects along elevational gradients: role of temperature and habitat diversity. Oecologia 188, 193-202. doi: $10.1007 / \mathrm{s} 00442-018-4169-4$

Cortois, R., Schröder-Georgi, T., Weigelt, A., van der Putten, W. H., and De Deyn, G. B. (2016). Plant-soil feedbacks: role of plant functional group and plant traits. J. Ecol. 104, 1608-1617. doi: 10.1111/1365-2745.12643

Cui, Z., Zhang, H., Chen, X., Zhang, C., Ma, W., Huang, C., et al. (2018). Pursuing sustainable productivity with millions of smallholder farmers. Nature 555, 363-366. doi: 10.1038/nature25785

Culina, A., Crowther, T. W., Ramakers, J. J. C., Gienapp, P., and Visser, M. E. (2018). How to do meta-analysis of open datasets. Nat. Ecol. Evol. 2, 1053-1056. doi: 10.1038/s41559-018-0579-2

Dainese, M., Riedinger, V., Holzschuh, A., Kleijn, D., Scheper, J., Steffan-Dewenter, I. (2018). Managing trap-nesting bees as crop pollinators: spatiotemporal effects of floral resources and antagonists. J. Appl. Ecol. 55, 195-204. doi: 10.1111/1365-2664.12930

De Long, J. R., Fry, E. L., Veen, G. F., and Kardol, P. (2018). Why are plant-soil feedbacks so unpredictable, and what to do about it? Funct. Ecol. 55, 195-204. doi: $10.1111 / 1365-2435.13232$

de Wit, C. T. (1960). On competition. Versl Landbouwkd Onderz 66, 1-82.

Dias, T., Dukes, A., and Antunes, P. M. (2015). Accounting for soil biotic effects on soil health and crop productivity in the design of crop rotations. J. Sci. Food Agric. 95, 447-454. doi: 10.1002/jsfa.6565

Dicks, L. V., Baude, M., Roberts, S. P., Phillips, J., Green, M., and Carvell, C. (2015). How much flower-rich habitat is enough for wild pollinators? Answering a key policy question with incomplete knowledge. Ecol. Entomol. 40, 22-35. doi: $10.1111 /$ een.12226

Dore, T., Makowski, D., Malezieux, E., Munier-Jolaind, N., Tchamitchiane, M. and Tittonell, P. (2011). Facing up to the paradigm of ecological intensification in agronomy: revisiting methods, concepts and knowledge. Eur. J. Agron. 34, 197-210. doi: 10.1016/j.eja.2011.02.006

Emam, T. (2016). Local soil, but not commercial AMF inoculum, increases native and non-native grass growth at a mine restoration site. Restor. Ecol. 24, 35-44. doi: 10.1111/rec.12287

Ettema, C. H., and Wardle, D. A. (2002). Spatial soil ecology. Trends Ecol. Evol. 17, 177-183. doi: 10.1016/S0169-5347(02)02496-5

Evers, J. B., Letort, V., Renton, M., and Kang, M. (2018). Computational botany: advancing plant science through functional-structural plant modelling. Ann. Bot. 121, 767-772. doi: 10.1093/aob/mcy050

Fahrig, L., Girard, J., Duro, D., Pasher, J., Smith, A., Javorek, S., et al. (2015). Farmlands with smaller crop fields have higher within-field biodiversity. Agric. Ecosyst. Environ. 200, 219-234. doi: 10.1016/j.agee.2014.11.018

Gallai, N., Salles, J.-M., Settele, J., and Vaissière, B. E. (2009). Economic valuation of the vulnerability of world agriculture confronted with pollinator decline. Ecol. Econ. 68, 810-821. doi: 10.1016/j.ecolecon.2008.06.014

Gange, A. C., and Smith, A. K. (2005). Arbuscular mycorrhizal fungi influence visitation rates of pollinating insects. Ecol. Entomol. 30, 600-606. doi: 10.1111/j.0307-6946.2005.00732.x

Garibaldi, L. A., Steffan-Dewenter, I., Winfree, R., Aizen, M. A., Bommarco, R., Cunningham, S. A., et al. (2013). Wild pollinators enhance fruit set 
of crops regardless of honey bee abundance. Science 339, 1608-1611. doi: $10.1126 /$ science. 1230200

Godfray, H. C., Beddington, J. R., Crute, I. R., Haddad, L., Lawrence, D., Muir, J. F., et al. (2010). Food security: the challenge of feeding 9 billion people. Science 327, 812-818. doi: 10.1126/science. 1185383

Grace, J. B., Schoolmaster, D. R., Guntenspergen, G. R., Little, A. M., Mitchell, B. R., Miller, K. M., et al. (2012). Guidelines for a graph-theoretic implementation of structural equation modeling. Ecosphere 3:art73. doi: 10.1890/ES12-00048.1

Gurr, G. M., Lu, Z., Zheng, X., Xu, H., Zhu, P., Chen, G., et al. (2016). Multicountry evidence that crop diversification promotes ecological intensification of agriculture. Nat. Plants 2:16014. doi: 10.1038/nplants.2016.14

Gurr, G. M., Wratten, S. D., Landis, D. A., and You, M. (2017). Habitat management to suppress pest populations: progress and prospects. Annu. Rev. Entomol. 62, 91-109. doi: 10.1146/annurev-ento-031616-035050

Haas, D., and Défago, G. (2005). Biological control of soil-borne pathogens by fluorescent pseudomonads. Nat. Rev. Microbiol. 3, 307-319. doi: $10.1038 /$ nrmicrol129

Hallmann, C. A., Sorg, M., Jongejans, E., Siepel, H., Hofland, N., Schwan, H., et al. (2017). More than 75 percent decline over 27 years in total flying insect biomass in protected areas. PLOS ONE 12:e0185809. doi: 10.1371/journal.pone.0185809

Hartmann, M., Frey, B., Mayer, J., Mäder, P., and Widmer, F. (2015). Distinct soil microbial diversity under long-term organic and conventional farming. ISME J. 9, 1177-1194. doi: 10.1038/ismej.2014.210

Hass, A. L., Kormann, U. G., Tscharntke, T., Clough, Y., Baillod, A. B., Siramiet, C. et al. (2018). Landscape configurational heterogeneity by small-scale agriculture, not crop diversity, maintains pollinators and plant reproduction in western Europe. Proc. R. Soc. B. 285:20172242. doi: 10.1098/rspb.2017.2242

Heinen, R., Biere, A., Harvey, J. A., and Bezemer, M. (2018). Effects of soil organisms on aboveground plant-insect interactions in the field: patterns, mechanisms and the role of methodology. Front. Ecol. Evol. 6:106. doi: 10.3389 /fevo.2018.00106

Holland, J. M., Bianchi, F. J., Entling, M. H., Moonen, A. C., Smith, B. M., and Jeanneret, P. (2016). Structure, function and management of semi-natural habitats for conservation biological control: a review of European studies. Pest Manag. Sci. 72, 1638-1651. doi: 10.1002/ps.4318

Holland, J. M., Smith, B. M., Storkey, J., Lutman, P. J. W., Aebischer, N. J. (2015). Managing habitats on English farmland for insect pollinator conservation. Biol. Conserv. 182, 215-222. doi: 10.1016/j.biocon.2014.12.009

Holtz, G., Brugnach, M., and Pahl-Wostl, C. (2008). Specifying "regime"-A framework for defining and describing regimes in transition research. Technol. Forecast. Soc. Change 75, 623-643 doi: 10.1016/j.techfore.2007.02.010

Ingerslew, K. S., and Kaplan, I. (2018). Distantly related crops are not better rotation partners for tomato. J. Appl. Ecol. 55, 2506-2516. doi: $10.1111 / 1365-2664.13156$

Jones, M. O., Allred, B. W., Naugle, D. E., Maestas, J. D., Donnelly, P., Metzet, L. J. et al. (2018). Innovation in rangeland monitoring: annual, $30 \mathrm{~m}$, plant functional type percent cover maps for U.S. rangelands, 1984-2017. Ecosphere 9:e02430. doi: 10.1002/ecs2.2430

Jordan, N., and Warner, K. D. (2010). Enhancing the multifunctionality of US agriculture. Bioscience 60, 60-66. doi: 10.1525/bio.2010.60.1.10

Kardol, P., Bezemer, T. M., and van der Putten, W. H. (2006). Temporal variation in plant-soil feedback controls succession. Ecol. Lett. 9, 1080-1088. doi: 10.1111/j.1461-0248.2006.00953.x

Karp, D. S., Chaplin-Kramer, R., Meehan, T. D., Martin, E. A., DeClerck, F., Grab, H., et al. (2018). Crop pests and predators exhibit inconsistent responses to surrounding landscape composition. Proc. Natl. Acad. Sci. U.S.A. 115:E7863E7870. doi: 10.1073/pnas.1800042115

Ke, P. J., Miki, T., and Ding, T. S. (2015). The soil microbial community predicts the importance of plant traits in plant-soil feedback. New Phytol. 206, 329-341. doi: $10.1111 /$ nph.13215

Kennedy, C. M., Lonsdorf, E., Neel, M. C., Williams, N. M., Ricketts, T. H., Winfree, R., et al. (2013). A global quantitative synthesis of local and landscape effects on wild bee pollinators in agroecosystems. Ecol. Lett. 16, 584-599. doi: 10.1111/ele.12082

Kessler, A., Duivenbooden, N., van, Nsabimana, F., and van Beek, C. L. (2016). Bringing ISFM to scale through an integrated farm planning approach: a case study from Burundi. Nutr. Cycl. Agroecosyst. 105, 249-261. doi: $10.1007 /$ s10705-015-9708-3
Kleijn, D., Bommarco, R., Fijen, T. P. M., Garibaldi, L. A., Potts, S. G., and van der Putten, W. H. (2018a). Ecological intensification: bridging the gap between science and practice. Trends Ecol. Evol. 34, 154-166. doi: 10.1016/j.tree.2018.11. 002

Kleijn, D., Linders, T. E. W., Stip, A., Biesmeijer, J. C., Wäckers, F. L., Bukovinszky, T. (2018b). Scaling up effects of measures mitigating pollinator loss from localto landscape-level population responses. Methods Ecol. Evol. 9, 1727-1738. doi: 10.1111/2041-210X.13017

Korthals, G. W., Thoden, T. C., van den Berg, W., and Visser, J. H. M. (2014). Longterm effects of eight soil health treatments to control plant-parasitic nematodes and Verticillium dahliae in agro-ecosystems. Appl. Soil. Ecol. 76, 112-123. doi: 10.1016/j.apsoil.2013.12.016

Kos, M., Bukovinszky, T., Mulder, P. P., and Bezemer, T. M. (2014). Disentangling above- and belowground neighbor effects on the growth, chemistry, and arthropod community on a focal plant. Ecology 96, 164-175. doi: $10.1890 / 14-0563.1$

Kostenko, O., van de Voorde, T. F., Mulder, P. P., van der Putten, W. H., and Bezemer, T. M. (2012). Legacy effects of aboveground-belowground interactions. Ecol. Lett. 15, 813-821. doi: 10.1111/j.1461-0248.2012.01801.x

Landis, D. A. (2017). Designing agricultural landscapes for biodiversity-based ecosystem services. Basic Appl. Ecol. 18, 1-12. doi: 10.1016/j.baae.2016.07.005

Landis, D. A., Wratten, S. D., and Gurr, G. M. (2000). Habitat management to conserve natural enemies of arthropod pests in agriculture. Annu. Rev. Entomol. 45, 175-201. doi: 10.1146/annurev.ento.45.1.175

Leach, J. E., Triplett, L. R., Argueso, C. T., and Trivedi, P. (2017). Communication in the phytobiome. Cell 169, 587-596. doi: 10.1016/j.cell.2017.04.025

Ledford, H. (2015). Plant dwellers take the limelight. Researchers seek holistic view of botanic ecosystems. Nature 523, 137-138. doi: 10.1038/523137a

Lennon, J. T., and Jones, S. E. (2011). Microbial seed banks: the ecological and evolutionary implications of dormancy. Nat. Rev. Microbiol. 9, 119-130. doi: $10.1038 /$ nrmicro 2504

Losey, J. E., and Vaughan, M. (2006). The economic value of ecological services provided by insects. Bioscience 56, 311-323. doi: 10.1641/00063568(2006)56[311:TEVOES]2.0.CO;2

Lucas-Barbosa, D., van Loon, J. J., and Dicke, M. (2011). The effects of herbivoreinduced plant volatiles on interactions between plants and flower-visiting insects. Phytochemistry 72, 1647-1654. doi: 10.1016/j.phytochem.2011.03.013

Lugtenberg, B., and Kamilova, F. (2009). Plant-growthpromoting rhizobacteria. Аnnu. Rev. Microbiol. 63, 541-556. doi: 10.1146/annurev.micro.62.081307.162918

Magrini, M.-B., Anton, M., Cholez, C., Corre-Hellou, G., Duc, G., Jeuffroy, M. H., et al. (2016). Why are grain-legumes rarely present in cropping systems despite their environmental and nutritional benefits? Analyzing lock-in in the French agrifood system. Ecol. Econ. 126, 152-162. doi: 10.1016/j.ecolecon.2016.03.024

Mallon, C. A., Elsas, J. D. V., and Salles, J. F. (2015). Microbial invasions: the process, patterns, and mechanisms. Trends Microbiol. 3, 719-729.doi: 10.1016/j.tim.2015.07.013

Mariotte, P., Mehrabi, Z., Bezemer, T. M., De Deyn, G. B., Kulmatiski, A., Drigo, B., et al. (2018). Plant-soil feedback: bridging natural and agricultural sciences. Trends Ecol. Evol. 33, 129-142. doi: 10.1016/j.tree.2017.11.005

Martin, A. R., and Isaac, M. E. (2015). Plant functional traits in agroecosystems: a blueprint for research. J. Appl. Ecol. 52, 1425-1435. doi: $10.1111 / 1365-2664.12526$

Martínez-García, L. B., Korthals, G., Brussaard, L., Jørgensen, H. B., and De Deyn, G. B. (2018). Organic management and cover crop species steer soil microbial community structure and functionality along with soil organic matter properties. Agric. Ecosyst. Environ. 263, 7-17. doi: 10.1016/j.agee.2018.04.018

Matson, P. A., Parton, W. J., Power, A. G., and Swift, M. J. (1997). Agricultural intensification and ecosystem properties. Science 277, 504-509. doi: $10.1126 /$ science. 277.5325 .504

Meynard, J.-M., Jeuffroy, M.-H., Le Bail, M., Le Baila, M., Lefèvre, A., Magrini, M. B., et al. (2017). Designing coupled innovations for the sustainability transition of agrifood systems. Agric. Syst. 157, 330-339. doi: 10.1016/j.agsy.2016.08.002

Middleton, E. L., and Bever, J. D. (2012). Inoculation with a native soil community advances succession in a grassland restoration. Restor. Ecol. 20, 218-226. doi: 10.1111/j.1526-100X.2010.00752.x

Morandin, L. A., Long, R. F., and Kremen, C. (2014). Hedgerows enhance beneficial insects on adjacent tomato fields in an intensive 
agricultural landscape. Agric. Ecosyst. Environ. 189, 164-170. doi: 10.1016/j.agee.2014.03.030

Morriën, E., Hannula, S. E., Snoek, L. B., Helmsing, N. R., Zweers, H., De Hollander, M., et al. (2017). Soil networks become more connected and take up more carbon as nature restoration progresses. Nat. Commun. 8:14349. doi: 10.1038/ncomms 14349

Müller, G., Kleunen, M., and van Dawson, W. (2016). Commonness and rarity of alien and native plant species - the relative roles of intraspecific competition and plant-soil feedback. Oikos 125, 1458-1466. doi: 10.1111/oik.02770

Orrell, P., and Bennett, A. E. (2013). How can we exploit above-belowground interactions to assist in addressing the challenges of food security? Front. Plant Sci. 4:432. doi: 10.3389/fpls.2013.00432

Oyserman, B. O., Medema, M. H., and Raaijmakers, J. M. (2018). Road MAPs to engineer host microbiomes. Curr. Opin. Microbiol. 43, 46-54. doi: 10.1016/j.mib.2017.11.023

Pineda, A., Kaplan, I., and Bezemer, T. M. (2017). Steering soil microbiomes to suppress aboveground insect pests. Trends Plant Sci. 22, 770-778. doi: 10.1016/j.tplants.2017.07.002

Pittelkow, C. M., Liang, X., Linquist, B. A., van Groenigen, K. J., Lee, J., Lundy, M. E., et al. (2015). Productivity limits and potentials of the principles of conservation agriculture. Nature 517, 365-368. doi: 10.1038/nature13809

Pretty, J. (2018). Intensification for redesigned and sustainable agricultural systems. Science 362:eaav0294. doi: 10.1126/science.aav0294

Pretty, J., Benton, T. G., Bharucha, Z. P., Dicks, L. V., Flora, C. B., Godfray, H. C. J., et al. (2018). Global assessment of agricultural system redesign for sustainable intensification. Nat. Sust. 1, 441-446. doi: 10.1038/s41893-018-0114-0

Quist, C. W., Gort, G., Mulder, C., Wilbers, R. H. P., Termorshuizen, A. J., Bakker, J., et al. (2017). Feeding preference as a main determinant of microscale patchiness among terrestrial nematodes. Mol. Ecol. Resour. 17, 1257-1270. doi: $10.1111 / 1755-0998.12672$

Raaijmakers, J. M., and Mazzola, M. (2016). Soil immune responses. Science 352, 1392-1393. doi: 10.1126/science.aaf3252

Raaijmakers, J. M., Paulitz, T. C., Steinberg, C., Alabouvette, A., and MoënneLoccoz, Y. (2009). The rhizosphere: a playground and battlefield for soilborne pathogens and beneficial microorganisms. Plant Soil 321, 341-361. doi: 10.1007/s11104-008-9568-6

Ramirez, K. S., Geisen, S., Morriën, E., Snoek, B. L., and van der Putten, W. H. (2018). Network analyses can advance above-belowground ecology. Trends Plant Sci. 3:759-768. doi: 10.1016/j.tplants.2018.06.009

Rashid, M. I., de Goede, R. G. M., Brussaard, L., and Lantinga, E. A. (2013). Home field advantage of cattle manure decomposition affects the apparent nitrogen recovery in production grasslands. Soil Biol. Biochem. 57, 320-326. doi: 10.1016/j.soilbio.2012.10.005

Rasmussen, L. V., Coolsaet, B., Martin, A., Mertz, O., Pascual, U., Corbera, E., et al. (2018). Social-ecological outcomes of agricultural intensification. Nat. Sust. 1, 275-282. doi: 10.1038/s41893-018-0070-8

Reynolds, H. L., Smith, A. A., and Farmer, J. R. (2014). Think globally, research locally: paradigms and place in agroecological research. Am. J. Bot. 101, 1631-1639. doi: 10.3732/ajb.1400146

Riedinger, V., Renner, M., Rundlöf, M., Steffan-Dewenter, I., and Holzschuh, A. (2013). Early mass-flowering crops mitigate pollinator dilution in lateflowering crops. Landsc. Ecol. 29, 425-435. doi: 10.1007/s10980-013-9973-y

Ritpitakphong, U., Falquet, L., Vimoltust, A., Berger, A., Métraux, J. P., and L'Haridon, F. (2016). The microbiome of the leaf surface of Arabidopsis protects against a fungal pathogen. New Phytol. 210, 1033-1043. doi: 10.1111/nph.13808

Rockström, J., Williams, J., Daily, G., Noble, A., Matthews, N., Gordon, L., et al. (2017). Sustainable intensification of agriculture for human prosperity and global sustainability. Ambio 46, 4-17. doi: 10.1007/s13280-016-0793-6

Roep, D., Van der Ploeg, J. D., and Wiskerke, J. S. C. (2003). Managing technicalinstitutional design processes: some strategic lessons from environmental co-operatives in the Netherlands. NJAS Wagening J. Life Sci. 51, 195-217. doi: 10.1016/S1573-5214(03)80033-7

Rowe, H. I., Brown, C. S., and Claassen, V. P. (2007). Comparisons of mycorrhizal responsiveness with field soil and commercial inoculum for six native montane species and Bromus tectorum. Restor. Ecol. 15, 44-52. doi: 10.1111/j.1526-100X.2006.00188.x

Rusch, A., Chaplin-Kramer, R., Gardiner, M. M., Hawro, V., Holland, J., Landis, D., et al. (2016). Agricultural landscape simplification reduces natural pest control: a quantitative synthesis. Agric. Ecosyst. Environ. 221, 198-204. doi: 10.1016/j.agee.2016.01.039

Sánchez-Cañizares, C., Jorrín, B., Poole, P. S., and Tkacz, A. (2017). Understanding the holobiont: the interdependence of plants and their microbiome. Curr. Opin. Microbiol. 38, 188-196. doi: 10.1016/j.mib.2017.07.001

Schellhorn, N. A., Gagic, V., and Bommarco, R. (2015). Time will tell: resource continuity bolsters ecosystem services. Trends Ecol. Evol. 30, 524-530. doi: 10.1016/j.tree.2015.06.007

Schrama, M., de Haan, J. J., Kroonen, M., Verstegen, H., and Van der Putten, W. H. (2018). Crop yield gap and stability in organic and conventional farming systems. Agric. Ecosyst. Environ. 256, 123-130. doi: 10.1016/j.agee.2017.12.023

Shackelford, G., Steward, P. R., Benton, T. G., Kunin, W. E., Potts, S. G., Biesmeijer, J. C., et al. (2013). Comparison of pollinators and natural enemies: a metaanalysis of landscape and local effects on abundance and richness in crops. Biol. Rev. Camb. Philos. Soc. 88, 1002-1021. doi: 10.1111/brv.12040

Shipley, B. (2016). Cause and Correlation in Biology: A User's Guide to Path Analysis, Structural Equations, and Causal Inference With R. Cambridge, MA: Cambridge University Press. doi: 10.1017/CBO9781139979573

Soler, R., van der Putten, W. H., Harvey, J. A., Vet, L. E. M., Dicke, M., and Bezemer, T. M. (2012). Root herbivore effects on aboveground multitrophic interactions: patterns, processes and mechanisms. J. Chem. Ecol. 6, 755-767. doi: 10.1007/s10886-012-0104-z

Steffan-Dewenter, I., Münzenberg, U., Bürger, C., Thies, C., and Tscharntke, T. (2002). Scale-dependent effects of landscape context on three pollinator guilds. Ecology 83, 1421-1432. doi: 10.1890/0012-9658(2002)083[1421:SDEOLC]2.0. $\mathrm{CO} ; 2$

Struik, P. C., and Kuyper, T. W. (2017). Sustainable intensification in agriculture: the richer shade of green. A review. Agron Sust. Dev. 37:39. doi: 10.1007/s13593-017-0445-7

Tamburini, G., De Simone, S., Sigura, M., Boscutti, F., and Marini, L. (2016). Soil management shapes ecosystem service provision and trade-offs in agricultural landscapes. Proc. R. Soc. B. 283:20161369. doi: 10.1098/rspb.2016.1369

Tittonell, P. (2014). Ecological intensification of agriculture - sustainable by nature. Curr. Opin. Environ. Sust. 8, 53-61. doi: 10.1016/j.cosust.2014.08.006

Tittonell, P., Klerkx, L., Baudron, F., Félix, G. F., Ruggia, A., van Apeldoorn, D., et al. (2016). "Ecological intensification: local innovation to address global challenges," in Sustainable Agriculture Reviews: Vol 19, ed E. Lichtfouse (Cham: Springer International Publishing), 1-34. doi: 10.1007/978-3-319-26777-7_1

Tscharntke, T., Klein, A. M., Kruess, A., Steffan-Dewenter, I., Thies, C. (2005). Landscape perspectives on agricultural intensification and biodiversity-ecosystem service management. Ecol. Lett. 8, 857-874. doi: $10.1111 / j .1461-0248.2005 .00782 . x$

Tschumi, M., Albrecht, M., Bärtschi, C., Collatz, J., Entling, M. H., and Jacot, K. (2016a). Perennial, species-rich wildflower strips enhance pest control and crop yield. Agric. Ecosyst. Environ. 220, 97-103. doi: 10.1016/j.agee.2016.01.001

Tschumi, M., Albrecht, M., Collatz, J., Dubsky, V., Entling, M. H., NajarRodriguez, A. J., et al. (2016b). Tailored flower strips promote natural enemy biodiversity and pest control in potato crops. J. Appl. Ecol. 53, 1169-1176. doi: 10.1111/1365-2664.12653

van Dam, N. M., and Heil, M. (2011). Multitrophic interactions below and above ground: en route to the next level. J. Ecol. 99, 77-88. doi: 10.1111/j.1365-2745.2010.01761.x

van der Heijden, M. G., Hartmann, M. (2016). Networking in the plant microbiome. PLoS Biol. 14:e1002378. doi: 10.1371/journal.pbio.1002378

van der Putten, W. H., Bardgett, R. D., de Ruiter, P. C., Hol, W. H., Meyer, K. M., Bezemer, T. M., et al. (2009). Empirical and theoretical challenges in aboveground-belowground ecology. Oecologia 161, 1-14. doi: 10.1007/s00442-009-1351-8

van der Putten, W. H., Vet, L. E. M., Harvey, J. A., and Wäckers, F. L. (2001). Linking above- and belowground multitrophic interactions of plants, herbivores, pathogens, and their antagonists. Trends Ecol. Evol. 16, 547-554. doi: 10.1016/S0169-5347(01)02265-0

van Groenigen, J. W., Lubbers, I. M., Vos, H. M., Brown, G. G., De Deyn, G. B., and van Groenigen, K. J. (2014). Earthworms increase plant production: a meta-analysis. Sci. Rep. 4:6365. doi: 10.1038/srep06365

van Lenteren, J. C. (2012). The state of commercial augmentative biological control: plenty of natural enemies, but a frustrating lack of uptake. Bio. Control 57, 1-20. doi: 10.1007/s10526-011-9395-1 
Veen, G. F. (Ciska), Freschet, G. T., Ordonez, A., and Wardle, D. A. (2015). Litter quality and environmental controls of home-field advantage effects on litter decomposition. Oikos 124, 187-195. doi: 10.1111/oik.01374

Veres, A., Petit, S., Conord, C., and Lavigne, C. (2013). Does landscape composition affect pest abundance and their control by natural enemies? A review. Agric Ecosyst. Environ. 166, 110-117. doi: 10.1016/j.agee.2011. 05.027

Wardle, D. A., Bardgett, R. D., Klironomos, J. N., Setälä, H., van der Putten, W. H., and Wall, D. H. (2004). Ecological linkages between aboveground and belowground biota. Science 304, 1629-1633. doi: 10.1126/science.1094875

Wiskerke, J. S. C., and Van der Ploeg, J. D. (2004). Seeds of Transition: Essays on Novelty Production, Niches and Regimes in Agriculture. Assen: Royal Van Gorcum.

Wubs, E. R. J., and Bezemer, T. M. (2018). Temporal carry-over effects in sequential plant-soil feedbacks. Oikos 127, 220-229. doi: 10.1111/oik.04526

Wubs, E. R. J., van der Putten, W. H., Bosch, M., and Bezemer, T. M. (2016). Soil inoculation steers restoration of terrestrial ecosystems. Nat. Plants 2:16107. doi: $10.1038 /$ nplants.2016.107

Wubs, E. R. J., van der Putten, W. H., Mortimer, S. R., Korthals, G. W., Duyts, H., Wagenaar, R., and Bezemer, T. M. (2019). Single introductions of soil biota and plants generate long-term legacies in soil and plant community assembly. Ecol. Lett. 22, 1145-1151. doi: 10.1111/ele.13271
Yang, J., Kloepper, J. W., and Ryu, C. M. (2009). Rhizosphere bacteria help plants tolerate abiotic stress. Trends Plant Sci. 14, 1-4. doi: 10.1016/j.tplants.2008.10.004

Zhang, F., and Li, L. (2003). Using competitive and facilitative interactions in intercropping systems enhances crop productivity and nutrient-use efficiency. Plant Soil 248, 305-312. doi: 10.1007/978-94-010-0243-1_26

Zuppinger-Dingley, D., Schmid, B., Petermann, J. S., Yadav, V., De Deyn, G. B., and Flynn, D. F. (2014). Selection for niche differentiation in plant communities increases biodiversity effects. Nature 515, 108-111. doi: 10.1038/nature13869

Conflict of Interest Statement: The authors declare that the research was conducted in the absence of any commercial or financial relationships that could be construed as a potential conflict of interest.

Copyright (c) 2019 Veen, Wubs, Bardgett, Barrios, Bradford, Carvalho, De Deyn, de Vries, Giller, Kleijn, Landis, Rossing, Schrama, Six, Struik, van Gils, Wiskerke, van der Putten and Vet. This is an open-access article distributed under the terms of the Creative Commons Attribution License (CC BY). The use, distribution or reproduction in other forums is permitted, provided the original author(s) and the copyright owner(s) are credited and that the original publication in this journal is cited, in accordance with accepted academic practice. No use, distribution or reproduction is permitted which does not comply with these terms. 